\section{Vitamin D plasma levels in a Romanian group of HIV-infected patients}

DOI: $10.1515 / \mathrm{rrlm}-2015-0036$

\section{To the Editor:}

Vitamin D (VD) is known for its essential role in the regulation of bone metabolism and homeostasis of calcium and phosphorus. Recent studies have shown also its pleiotropic, noncalcemic benefits: modulation of immune response, prevention of autoimmune diseases and malignant transformations, role in the modulation of glucose metabolism by stimulation of insulin secretion and prevention of cardiovascular diseases (1-3). Vitamin D modulates innate immunity by inducing the production of peptides with antimicrobial activity, such as cathelicidin and human $\beta$-defensine 2 (hBD2) (4) by increasing NADPH oxidase activity in monocytes, stimulation of degradation by the cells' own cellular components (autophagy), important in immune defense against $M$. tuberculosis and support the integrity and maintenance of the physical barrier function (5-7). Immunoregulatory activity on the adaptive immunity involves the inhibitory effect of VDR (Vitamin D Receptor) agonists on the proinflammatory $\mathrm{T}$ lymphocyte subsets (Th1, Th17), favoring deviation of the immune response to the Th2 line. The VDR agonist effect can modulate the development of chronic inflammatory diseases and tissue destruction processes (8).

Activation of VDR inhibits $B$ cell proliferation, memory $\mathrm{B}$ cell generation by class-switch, plasma cell differentiation and immunoglobulin production (9).

VD favors the Th2-type immune response, facilitates Treg cell activity and inhibits Th17 cell development (1).
Vitamin D deficiency is a worldwide problem, even in countries where the number of hours of sunshine could provide the necessary synthesis of VD (10).

In patients with HIV/AIDS low levels of VD were recorded comparatively with reported reference values (11-13).

Our purpose was to evaluate plasma vitamin D levels among patients with HIV infection with or without TB coinfection and antiretroviral therapy from Tîrgu Mureș Regional HIV/ AIDS Centre.

Between October 2012 - February 2013 a cross-sectional study was organized and 65 HIV-infected adult patients (with or without antiretroviral therapy) were examined. All adult patients presented for clinical, immunological and virological evaluation to HIV/AIDS ambulatory during this period were included in the study group. The exclusion criteria were the VD supplements administration. The control group consisted of 10 apparently healthy adults.

This study was approved by the Ethics Committee of University of Medicine and Pharmacy Tîrgu Mureș and subjects gave their informed consent.

Collected data included absolute CD4 cell count (CD4/CD8/CD3 FACScan, Becton Dickinson) and plasma viral load (HIV-VL) (Ampliprep/TaqMan HIV-1 test, Roche Diagnostics). The measurements were performed at scheduled visits for monitoring antiretroviral (ARV) therapy. Other collected parameters were: ARV regimen, the presence of TB (tuberculosis) coinfection (confirmed by positive culture for $M$. $t u$ berculosis), vitamin D plasma level, Body Mass Index (BMI) and patients demographics (age, gender distribution). Vitamin D plasma levels were determined with 25-OH Vitamin D ELISA (EUROIMMUN EQ 6411-9601) kit, with mono- 
clonal antibodies which specifically bounds to $25-\mathrm{OH}$ vitamin $\mathrm{D} 3$ and $25-\mathrm{OH}$ vitamin $\mathrm{D} 2$. The detection limit of 25-OH Vitamin D by this method was $1.9 \mathrm{ng} / \mathrm{ml}$. Cross reactions with other metabolites: vitamin D3 (cholecalciferol) and vitamin D2 (ergocalciferol): $<0.02 \%$, cholesterol: $<0.04 \%$.

We considered the optimal level of plasma VD $>30 \mathrm{ng} / \mathrm{mL}$, suboptimal/insufficient VD: 20-30 ng/mL, VD deficiency $<20 \mathrm{ng} / \mathrm{mL}(14,15)$ and toxicity above $150 \mathrm{ng} / \mathrm{mL}$ (16).

Statistical analysis was performed with GraphPad Prism 6 and DSS research tool for statistical power calculation. Continuous variables were reported as medians and 25th to 75th percentiles (IQR). Quantitative data were compared using unpaired $t$-test for normal distributions variables. Variables with non-normal distribution were analyzed with Mann Whitney
$U$ test. Proportions were reported as percentages and compared with Fisher's exact test.

The study group included $65 \mathrm{C}$-stage (CDC classification) HIV-infected patients, 38 (58.4\%) men and 27 (41.5\%) women; 5 patients had liver disease (B, C hepatitis, cirrhosis). Demographic, immunological, virological characteristics and plasma VD levels in studied groups are showed in table Ia.

Significant difference was obtained between vitamin D plasma levels in patients' group and in healthy people $(p=0.003)$. No significant differences between CD4 cell count, viral load and plasma VD level between men and women was obtained. No significant differences were observed between CD4 cell count in patients with optimal, insufficient or low VD plasma level.

From 65 patients enrolled, $14(21.5 \%)$ had HIV/TB (tuberculosis) coinfection. No signif-

Table Ia. Demographic, immuno-virological characteristics and plasma vitamin D levels in studied groups.

\begin{tabular}{|c|c|c|c|c|}
\hline $\begin{array}{l}\text { Group (N) } \\
\text { Criteria }\end{array}$ & $\begin{array}{l}\text { Control group } \\
(10)\end{array}$ & $\begin{array}{c}\text { HIV infected } \\
\text { patients group }(65)\end{array}$ & $\begin{array}{l}\text { HIV/TB coinfection } \\
\text { subgroup (14) }\end{array}$ & $\begin{array}{c}\text { HIV without TB } \\
\text { coinfection subgroup } \\
(51)\end{array}$ \\
\hline $\begin{array}{l}\text { Age (years) } \\
\text { median (IQR) }\end{array}$ & $31(25.75-34)$ & $23(22-27.5)$ & $23(21-39.5)$ & $23(23-27)$ \\
\hline $\begin{array}{l}\text { BMI }(\mathrm{kg} / \mathrm{m} 2) \\
\text { median }(\mathrm{IQR})\end{array}$ & $22.44(21.02-22.94)$ & $21.1(19.1-24.4)$ & $20.8(17.90-23.03)$ & $20.97(19.16-23.76)$ \\
\hline Male/Female & $1 / 9$ & $38 / 27$ & $9 / 5$ & $29 / 22$ \\
\hline $\begin{array}{l}\mathrm{CD} 4 \text { cells } / \mu \mathrm{L} \\
\text { median (IQR) }\end{array}$ & - & $372.5(221.5-798.3)$ & $337(97.5-502.3)$ & $388(227.3-893)$ \\
\hline $\begin{array}{l}\mathrm{VL}(\text { copies } / \mathrm{mL}) \\
\text { median (IQR) }\end{array}$ & - & $25(0-2350)$ & $3845(291.8-36.230)^{*}$ & $20(0-1426)$ \\
\hline $\begin{array}{l}\text { VD level ng/mL } \\
\text { median (IQR) }\end{array}$ & $39.3(32.6-56.27)$ & $29.6(19.69-39.2)^{*}$ & $29.21(17.02-34.34)$ & $28.05(20.35-39.2)$ \\
\hline $\begin{array}{l}\text { VD deficiency } \\
(<20 \mathrm{ng} / \mathrm{mL}) \\
\mathrm{N}(\%) \\
\end{array}$ & - & $16(24.6 \%)$ & $5(35.7 \%)$ & $11(21.6 \%)$ \\
\hline $\begin{array}{l}\text { VD insufficiency } \\
(20-30 \mathrm{ng} / \mathrm{mL}) \\
\mathrm{N}(\%) \\
\end{array}$ & $1(10 \%)$ & $20(30.8 \%)$ & $2(14.3 \%)$ & $18(35.2 \%)$ \\
\hline $\begin{array}{l}\text { Optimal VD } \\
(>30 \mathrm{ng} / \mathrm{mL}) \\
\mathrm{N}(\%)\end{array}$ & $9(90 \%)$ & $29(44.6 \%)$ & $7(50 \%)$ & $22(43.2 \%)$ \\
\hline
\end{tabular}

$* \mathrm{p}<0.05$ 
Table Ib. The immunological and virological characteristics of patients defined on plasma vitamin D levels

\begin{tabular}{|c|c|c|c|}
\hline & $\begin{array}{c}\text { HIV infected } \\
\text { patients group (65) }\end{array}$ & $\begin{array}{l}\text { HIV/TB coinfection } \\
\text { subgroup (14) }\end{array}$ & $\begin{array}{c}\text { HIV without TB } \\
\text { coinfection subgroup (51) }\end{array}$ \\
\hline \multicolumn{4}{|l|}{$\begin{array}{l}\text { VD deficiency } \\
(<20 \mathrm{ng} / \mathrm{mL})\end{array}$} \\
\hline $\begin{array}{l}\mathrm{CD} 4 \text { cells/ } \mu \mathrm{L} \\
\text { median (IQR) }\end{array}$ & $\begin{array}{c}369.00 \\
(126-672.5)\end{array}$ & $\begin{array}{c}369 \\
(153.5-464.5)\end{array}$ & $\begin{array}{c}577 \\
(126-979)\end{array}$ \\
\hline $\begin{array}{l}\text { VL }(\text { copies } / \mathrm{mL}) \\
\text { median }(\mathrm{IQR})\end{array}$ & $\begin{array}{c}972 \\
(20-16294)\end{array}$ & $\begin{array}{c}26580 * \\
(486.5-281805)\end{array}$ & $\begin{array}{c}20 \\
(0-1982)\end{array}$ \\
\hline \multicolumn{4}{|c|}{$\begin{array}{l}\text { Insufficient VD level } \\
(20-30 \mathrm{ng} / \mathrm{mL})\end{array}$} \\
\hline $\begin{array}{l}\mathrm{CD} 4 \text { cells } / \mu \mathrm{L} \\
\text { median (IQR) }\end{array}$ & $\begin{array}{c}376 \\
(241-941)\end{array}$ & $\begin{array}{c}308.5 \\
-\end{array}$ & $\begin{array}{c}540 \\
232-970.5\end{array}$ \\
\hline $\begin{array}{l}\mathrm{VL}(\text { copies } / \mathrm{mL}) \\
\text { median }(\mathrm{IQR})\end{array}$ & $\begin{array}{c}20 \\
(0-189)\end{array}$ & $\begin{array}{c}8231 \\
-\end{array}$ & $\begin{array}{c}20 \\
(0-62)\end{array}$ \\
\hline \multicolumn{4}{|l|}{$\begin{array}{l}\text { Optimal VD level } \\
(>30 \mathrm{ng} / \mathrm{mL})\end{array}$} \\
\hline $\begin{array}{l}\text { CD4 cells } / \mu \mathrm{L} \\
\text { median }(\mathrm{IQR})\end{array}$ & $\begin{array}{c}346.5 \\
(225.25-754)\end{array}$ & $\begin{array}{c}305 \\
(22-735)\end{array}$ & $\begin{array}{c}347 \\
(278-811)\end{array}$ \\
\hline $\begin{array}{l}\text { VL (copies/mL) } \\
\text { median (IQR) }\end{array}$ & $\begin{array}{c}69 \\
(10-6731.5)\end{array}$ & $\begin{array}{c}2565.0 * \\
(39-22586)\end{array}$ & $\begin{array}{c}43 \\
(0-6281.25)\end{array}$ \\
\hline
\end{tabular}

$* \mathrm{p}<0.05$

Vitamin D is synthesized in the skin from icant differences were identified in CD4 cell counts and plasma VD levels between patients with or without TB coinfection (table Ib). Patients with HIV/TB coinfection had significantly higher viral load compared to those without TB coinfection $(\mathrm{p}=0.03)$. In HIV/TB coinfection group patients with VD deficiency $(<20 \mathrm{ng} / \mathrm{mL})$ and those with optimal VD level $(>30 \mathrm{ng} / \mathrm{mL})$ had significantly higher viral load compared to those without TB coinfection and suboptimal (20-30 ng/mL) VD level (table Ib).

40 patients received ARV therapy that can induce hypovitaminosis D (efavirenz, saquinavir, kaletra, delavirdine, telzir, atazanavir) (17). No differences were obtained in plasma vitamin $\mathrm{D}$ levels between groups in which ARVs were administered (27.54; IQR 19.15-37.83 ng/ml) and those in which these substances were not administered (20.92; IQR 20.92-40.97 ng/ml).

No significant differences were identified between median BMI according to plasma VD levels. 7-dehydrocholesterol under catalytic effect of UVB radiation. From the skin cells, vitamin $\mathrm{D}_{3}$ reaches the bloodstream, where it binds to the vitamin D-binding protein (DBP). The activation of vitamin D requires two steps of hydroxylation: at the 25-position, cathalyzed by 25 -hydroxylase Cyp2R1 or Cyp27A1 that occurs in the liver and the hydroxylation at the 1-position, cathalyzed by 1-alpha-hydroxylase (Cyp27B1); the active 1,25-dihydroxyvitamin $\mathrm{D}$, named calcitriol, results. This step may take place in the epithelium of the kidneys, also called the endocrine pathway. Another activation pathway of vitamin D- the autocrine/paracrine pathway - takes place in a number of cells in the body, particularly in the cells of the immune system: monocytes, macrophages, dendritic cells, $\mathrm{T}$ cells and B cells. Vitamin D produced by immune cells may contribute to the regulation of anti-infectious response and immune tolerance $(18,19)$. 
For evaluation of vitamin D status, the Endocrine Society's Clinical Practice Guideline recommends plasma $25(\mathrm{OH}) \mathrm{D}$ level, that is the major circulating form of vitamin $\mathrm{D}$ (14). Optimal levels of $25(\mathrm{OH}) \mathrm{D}$ are widely discussed in the literature, given the wide variety of methods used and the lack of calibrators in order to compare results obtained by different methods (20). Biological variability of $25(\mathrm{OH}) \mathrm{D}$ levels in the plasma is less studied. Brinkley et al. consider intra-individual variability between 13-19\% (21). Viljoen reported the value of intra-patient variability of $12 \%$, while the inter-individual variability $-43 \%$ (22). Brescia found values of $4.7 \%$ and $64.3 \%$ for these parameters (23). Establishing the optimal plasma levels of this metabolite is cumbersome due to the aspects listed above. In our study we have reported reference values indicated by bibliographic sources $(3,14)$. Brienkley et al. consider "given the presence of analytic and biologic variability its seems reasonable that clinicians consider using $25(\mathrm{OH})$ D concentrations of approximate 35 to $40 \mathrm{ng} / \mathrm{mL}$ as therapeutic goal" (21). The major causes of vitamin D deficiency are the inadequate exposure to sunlight, the use of sunscreen protection, and the dark skin. Many pathological conditions may affect the vitamin D status: vitamin D deficiency is highly prevalent in obesity (BMI $>30 \mathrm{~kg} / \mathrm{m}^{2}$ ), malabsorption syndromes, in use of ARV for AIDS/HIV treatment $(14,17,24)$. In our study there were no obese patients and we found no correlation between patient's BMI and vitamin D plasma levels. The Endocrine Society recommends measurement of circulating vitamin D levels in all patients with antiretroviral therapy (14), while the European AIDS Clinical Society recommended dosage of vitamin D in individuals receiving efavirenz (15). We have not found correlation between the administration of ARVs and VD deficiency.

In our group almost half of patients (47\%) had suboptimal levels of VD, and $24 \%$ had in- sufficient VD levels. Our results are comparable with those reported in the literature: $41-81 \%$ of HIV-infected patients have suboptimal levels of VD $(2,13)$. The relatively lower percentage of patients with vitamin D insufficiency is probably due to the relatively low number of tested patients, the structure of the group of patients (relatively young people), and the differences arising from the biological variability (23).

In the literature there are contradictory studies, some of them reported correlation between administration of VD and increase of CD4 cell count or decrease in viral load in HIV-infected persons $(3,25)$ and there are other studies that did not report similar correlations (26). We did not find an association between plasma VD levels, CD4 cell count and plasma viral load.

In our study, half of patients with HIV/TB coinfection had VD insufficiency/deficiency. There are studies which showed that low VD levels favor increased risk of active TB infection (27), but in our study we did not find relationship between low VD plasma level and presence of active TB infection.

In our study about half of patients with HIV infection/AIDS had significantly lower levels of plasma vitamin D compared to healthy individuals, without differences regarding HIV/TB coinfection. Based on these data we consider mandatory the measurement of vitamin D plasma levels in all patients with HIV infection/AIDS and vitamin D supplementation, according to the observed deficit.

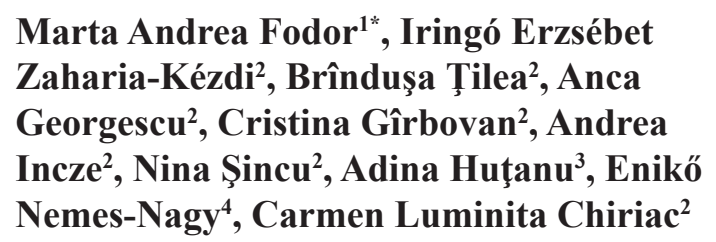

1. University of Medicine and Pharmacy Tîrgu Mureş, Romania

2. Department of Infectious Diseases, University 
of Medicine and Pharmacy Tîrgu Mureş, Clinic of Infectious Diseases, Tîrgu Mureş, Romania 3. Emergency Clinical County Hospital Tîrgu Mureş, Romania

4. Department of Biochemistry, University of Medicine and Pharmacy Tîrgu Mureş, Romania

* Corresponding author: Marta Andrea Fodor, email: andrea.fodor@ymail.com

\section{Conflict of interest}

The authors declare that there are no conflicts of interest.

Received: $5^{\text {th }}$ November 2014; Accepted: $14^{\text {th }}$ September 2015; Published: $3^{\text {rd }}$ December 2015

\section{References}

1. Aranow C. Vitamin D and the Immune System. J Investig Med. 2011 Aug;59(6):881-6. DOI: 10.231/ JIM.0b013e31821b8755

2. Legeai C, Vigouroux C, Souberbielle J-C, Bouchaud O, Boufassa F, Bastard J-P, et al. Associations between 25-Hydroxyvitamin D and Immunologic, Metabolic, Inflammatory Markers in Treatment-Naive HIV-Infected Persons: The ANRS CO9 «COPANA» Cohort Study. PLoS ONE. 2013 Sep 18;8(9):e74868. DOI: 10.1371/journal.pone.0074868

3. Villamor E. A potential role for vitamin D on HIV infection? Nutr Rev. 2006 May;64(5 Pt 1):226-33. DOI: 10.1111/j.1753-4887.2006.tb00205.x

4. Wang T-T, Nestel FP, Bourdeau V, Nagai Y, Wang Q, Liao J, et al. Cutting Edge: 1,25-Dihydroxyvitamin D3 Is a Direct Inducer of Antimicrobial Peptide Gene Expression. J Immunol. 2004 Sep 1;173(5):2909-12. DOI: 10.4049/jimmunol.173.5.2909

5. Yuk J-M, Shin D-M, Lee H-M, Yang C-S, Jin HS, Kim $\mathrm{K}-\mathrm{K}$, et al. Vitamin D3 Induces Autophagy in Human Monocytes/Macrophages via Cathelicidin. Cell Host Microbe. 2009 Sep 17;6(3):231-43. DOI: 10.1016/j. chom.2009.08.004

6. Hewison M, Zehnder D, Chakraverty R, Adams JS. Vitamin D and barrier function: a novel role for extra-renal 1 alpha-hydroxylase. Mol Cell Endocrinol. 2004 Feb 27;215(1-2):31-8. DOI: 10.1016/j.mce.2003.11.017

7. Schauber J, Dorschner RA, Coda AB, Büchau AS, Liu
PT, Kiken D, et al. Injury enhances TLR2 function and antimicrobial peptide expression through a vitamin D-dependent mechanism. J Clin Invest. 2007 Mar 1;117(3):803-11. DOI: 10.1172/JCI30142

8. Adorini L. Control of Adaptive Immunity by Vitamin D Receptor Agonists. In: Feldman D, J. Wesley P, Adams JS, editors. Vitamin D, Academic Press; 2011. p.1789809. DOI: 10.1016/b978-0-12-381978-9.10092-7

9. Chen S, Sims GP, Chen XX, Gu YY, Chen S, Lipsky PE. Modulatory effects of 1,25-dihydroxyvitamin D3 on human B cell differentiation. J Immunol Baltim Md 1950. 2007 Aug 1;179(3):1634-47.

10. Mithal A, Wahl DA, Bonjour J-P, Burckhardt P, Dawson-Hughes B, Eisman JA, et al. Global vitamin D status and determinants of hypovitaminosis D. Osteoporos Int. 2009 Nov;20(11):1807-20. DOI: 10.1007/s00198009-1030-y DOI: 10.1007/s00198-009-0954-6

11. Wasserman P, Rubin DS. Highly prevalent vitamin $\mathrm{D}$ deficiency and insufficiency in an urban cohort of HIV-infected men under care. AIDS Patient Care STDs. 2010 Apr;24(4):223-7. DOI: 10.1089/apc.2009.0241

12. Mueller NJ, Fux CA, Ledergerber B, Elzi L, Schmid $\mathrm{P}$, Dang $\mathrm{T}$, et al. High prevalence of severe vitamin $\mathrm{D}$ deficiency in combined antiretroviral therapy-naive and successfully treated Swiss HIV patients. AIDS. 2010 May 15;24(8):1127-34. DOI: 10.1097/ QAD.0b013e328337b161

13. Bang UC, Shakar SA, Hitz MF, Jespersen MS, Andersen O, Nielsen SD, et al. Deficiency of 25-hydroxyvitamin D in male HIV-positive patients: A descriptive cross-sectional study. Scand J Infect Dis. 2010 Jan 19;42(4):306-10. DOI: 10.3109/00365540903463981

14. Holick MF, Binkley NC, Bishoff-Ferrari HA, Gordon CM, Hanley DA, Heaney RP et al. Evaluation, Treatment, and Prevention of Vitamin D Deficiency: An Endocrine Society Clinical Practice Guideline. J Clin Endocrinol Metab. 2011 Jul; 96(7):1911-30. DOI: 10.1210/jc.2011-0385

15. European AIDS Clinical Society Guidelines 7.02.2014: http://www.eacsociety.org/Portals/0/140601_ EACS\%20EN7.02.pdf

16. Ozkan B, Hatun S, Bereket A. Vitamin D intoxication. Turk J Pediatr. 2012 Apr; 54(2):93-8.

17. Welz T, Childs K, Ibrahim F, Poulton M, Taylor CB, Moniz CF, et al. Efavirenz is associated with severe vitamin D deficiency and increased alkaline phosphatase. AIDS. 2010 Jul; 24(12):1923-8. DOI: 10.1097/QAD. 
0b013e32833c3281

18. Whiting SJ, Calvo MS. Nutrition and Lifestyle Effects on Vitamin D Status. In: Feldman D, J. Wesley P, Adams JS, editors. Vitamin D. Academic Press; 2011. p.979-1007. DOI: 10.1016/b978-0-12-3819789.10054-X

19. Han Y-P, Kong M, Zheng S, Ren Y, Zhu L, Shi H, et al. Vitamin D in liver diseases: From mechanisms to clinical trials. J Gastroenterol Hepatol. 2013 Aug 1;28:4955. DOI: 10.1111 jgh. 12016

20. Hollis BW. Detection of Vitamin D and its Major Metabolites. In: Feldman D, J. Wesley P, Adams JS, editors. Vitamin D. Academic Press; 2011. p.823-44. DOI: 10.1016/b978-0-12-381978-9.10047-2

21. Binkley N, Ramamurthy R, Krueger D. Low Vitamin D Status: Definition, Prevalence, Consequences, and Correction. Endocrinol Metab Clin North Am. 2010 Jun; 39(2):287-301. DOI: 10.1016/j.ecl.2010.02.008

22. Viljoen A, Singh DK, Farrington K, Twomey PJ. Analytical quality goals for 25-vitamin $\mathrm{D}$ based on biological variation. J Clin Lab Anal. 2011;25(2):130-3. DOI: 10.1002/jcla.20446

23. Brescia V. Biological Variability of Serum 25-Hydroxyvitamin D and Other Biomarkers in Healthy Subjects. LabMedicine. 2013;44(1):20-24. DOI: 10.1309/ lmf62nsleryc8pad

24. Adeyemi OM, Agniel D, French AL, Tien PC, Weber $\mathrm{K}$, Glesby MJ, et al. Vitamin D deficiency in HIV-infected and HIV-uninfected women in the United States. J Acquir Immune Defic Syndr. 2011 Jul 1;57(3):197204. DOI: 10.1097/QAI.0b013e31821ae418

25. Bearden A, Abad C, Gangnon R, Sosman JM, Binkley N, Safdar N. Cross sectional study of vitamin D levels, immunologic and virologic outcomes in HIV-infected adults. J Clin Endocrinol Metab. April 2013, 98(4):1726-1733. DOI: 10.1210/jc.2012-4031

26. Mehta S, Giovannucci E, Mugusi FM, Spiegelman D, Aboud S, Hertzmark E, et al. Vitamin D Status of HIV-Infected Women and Its Association with HIV Disease Progression, Anemia, and Mortality. PLoS ONE. 2010 Jan 19;5(1):e8770. DOI: 10.1371/journal. pone. 0008770

27. Salahuddin N, Ali F, Hasan Z, Rao N, Aqeel M, Mahmood F. Vitamin D accelerates clinical recovery from tuberculosis: results of the SUCCINCT Study [Supplementary Cholecalciferol in recovery from tuberculosis]. A randomized, placebo-controlled, clinical trial of vitamin D supplementation in patients with pulmonary tuberculosis'. BMC Infect Dis. 2013 Jan 19;13(1):22. DOI: $10.1186 / 1471-2334-13-22$ 